University of Nebraska - Lincoln

DigitalCommons@University of Nebraska - Lincoln

Space, Cyber, and Telecommunications Law

Program Faculty Publications

6-2009

\title{
Space Law in the Age of the International Space Station
}

Frans von der Dunk

University of Nebraska - Lincoln, fvonderdunk2@unl.edu

Follow this and additional works at: https://digitalcommons.unl.edu/spacelaw

Part of the Air and Space Law Commons

von der Dunk, Frans, "Space Law in the Age of the International Space Station" (2009). Space, Cyber, and Telecommunications Law Program Faculty Publications. 6.

https://digitalcommons.unl.edu/spacelaw/6

This Article is brought to you for free and open access by the Law, College of at DigitalCommons@University of Nebraska - Lincoln. It has been accepted for inclusion in Space, Cyber, and Telecommunications Law Program Faculty Publications by an authorized administrator of DigitalCommons@University of Nebraska - Lincoln. 
Published (as Chapter 4) in Humans in Outer Space - Interdisciplinary Odysseys, ed. Luca Codignola, Kai-Uwe Schrogl, Agnieszka Lukaszczyk, and Nicolas Peter (SpringerVienna, 2009), pp. I48-16I; doi: 10. I007/978-3-2 I -87465-3 (Volume I of Studies in Space Policy series). Used by permission.

Published online June 18, 2009

\section{Space Law in the Age of the International Space Station}

Frans G. von der Dunk

University of Nebraska College of Law

\section{Introduction}

This article focuses on the special context where humans from various nations work and live together in one orbiting laboratory, the International Space Station (ISS), and the legal rules pertinent to those activities. This essentially concerns the application of an existing body of international treaties on space and space activities to the ISS, as well as the special legal framework that has been established to deal with the various ramifications of this very international operating environment. Within that context moreover, the specific European parameters stemming from the fact that the European Space Agency (ESA) serves as the vehicle for the participation of 11 European states in the ISS deserve special attention. The totality of this set of rules, though in several instances not yet elaborated as extensively as might be desired, does provide for a dedicated comprehensive legal framework that may serve as an interesting example of international space law also with a view to future developments.

\section{Towards an International Space Station}

\section{I.The background of the initiative to build an International Space Station}

Between the moon landings of the early 1970s and the sudden appearance of the prospects of space tourism a few years ago, the most interesting space-related activities were the efforts to build an International Space Station. Although it never captured the imagination of the general public like the Apollo program did, or even tickled the imagination of some parts of the general public like the sight of adventurous millionaires going into outer space for fun did, the gradual extension of human presence into outer space - as regards duration and scope of ac- 
tivity - through a space station built, launched and operated as a joint international enterprise, was audacious in many ways, not least of all legally.

The idea of launching an international space station evolved from the interest of the U.S. in cooperating with some of its major political partners in the peaceful exploration and use of outer space in a more substantive and consistent fashion than up to then. There had already been a number of essentially bilateral cooperation projects in the area of outer space between the U.S. and, for example, a number of European states collectively such as the Skylab and Spacelab missions. But all of them had been essentially short-term projects, rather than longterm programs, and none had the same geo-political drive behind them. Thus, in 1984, U.S. President Ronald Reagan mandated the U.S. agency responsible for national civilian space efforts, the National Aeronautical and Space Administration (NASA), to develop a space station and invite relevant partners to join the effort technically, operationally and financially. ${ }^{137}$

\subsection{From the first to the second Intergovernmental Agreement}

These efforts led to the first Intergovernmental Agreement of $1988^{138}$ between the U.S., Japan, Canada and a number of European states (ultimately amounting to eleven) ${ }^{139}$ represented collectively by the European Space Agency (ESA) ${ }^{140}$ on the design, development, operation and utilization of a space station, which at the time was called "Freedom." The first part of the space station, which was to be assembled in space following a whole series of launches, measured $110 \mathrm{~m}$ across and $90 \mathrm{~m}$ long with a total weight of about 1 million pounds and was would actually launched in November 1998, with final completion scheduled for 2010 or shortly thereafter. ${ }^{141}$

However, even before the 1988 Intergovernmental Agreement had formally entered into force, the Soviet Union and the attendant political Communist structures fell apart, creating a completely new geo-political paradigm as a backdrop to the whole space station project.

On the one hand, the end of the Cold War meant-for all practical purposes - the removal of political and ideological barriers against using Soviet/Russian technological experience, software and hardware (which in terms of long-duration human spaceflight was by far outstanding versus all the West was able to muster). On the other hand, from the Western perspective, the risk of highly qualified Russian engineers fleeing the financially deteriorating situation at home (where the space industry was no longer a top priority) and seeking employment with whoever was 
willing to pay was not to be taken lightly. As a result, Russia was successfully invited to join the international partnership. The 1988 Intergovernmental Agreement was renegotiated and ultimately transformed into the 1998 version. ${ }^{142}$ "Freedom" was simply renamed "the International Space Station," or "ISS."

For the sake of completeness, it should be added that one more state, Brazil, has effectively become a formal part of the legal construction supporting the ISS venture since then, but as a special partner-namely through a bilateral agreement with the U.S. under the arrangements pertinent to the planned utilization by Brazil of the U.S. modules of the ISS. In this context, the U.S. had to notify in advance, and seek timely consensus from, the other space station partners. ${ }^{143}$

\subsection{The legal construction underpinning the International Space Station}

Overall, the legal construction underpinning the ISS consisted of several layers, with the Intergovernmental Agreement obviously acting as the over- arching umbrella for all legal aspects. At a second level, Memoranda of Understanding were concluded between NASA, on the one hand, and the other Cooperating Agencies on the other, to deal with many of the more practical details of developing the ISS. One level further below implementing arrangements were to be concluded whenever necessary between the cooperating agencies concerned. ${ }^{144}$

All the contracts and subcontracts further down the chain, principally between the cooperating agencies and industrial partners charged to develop certain parts of the ISS, were not officially referred to in the Intergovernmental Agreement, yet fall clearly into its scope of application, as well as of the relevant Memoranda of Understanding and implementing arrangements.

A final remark concerns access to the space station. With the accession of Russia to the undertaking of the ISS, transportation to and from the ISS as regards astronauts and cosmonauts was to be offered by Space Shuttle and Soyuz vehicles, while the European partners and Japan were bent on developing cargo vehicles. As a consequence of the basic "no exchange of funds" philosophy underlying the ISS undertaking, the provision of such transportation services - which for several reasons could not be dealt with feasibly on the basis of "in kind" compensation-needed to be carved out from that approach by means of a special exception. ${ }^{145}$ The "no exchange of funds" basis was not applied to Russia in view of the aforementioned rationale for taking Russia on board, but this was also clearly an exception dictated by ulterior motives, without impinging upon the underlying philosophy of the joint venture. 


\section{The novelty of the International Space Station}

\section{I. From short-haul flights to a long-haul presence in outer space}

Politically, of course, the inclusion of Russia, the former Cold War enemy of the other partner states in the cooperative venture, which was shaped in the 1990 and culminated in the 1998 Intergovernmental Agreement, was already a novelty - at least for such a highly visible, high techarea with many security-sensitive aspects as building a station orbiting in outer space.

More important from a legal perspective at least was the envisaged quasi- permanency of the station. While the longevity of MIR, resulting in nearly 15 years of orbital lifetime, was in many respects a matter of surprise-as well as keeping it alive on a shoestring almost literally - the ISS was from the start destined to serve for decades, as "a permanently inhabited civil international space station." 146 Hence, from the start, it was also envisaged to serve a wider variety of human activities, far beyond the mere traffic or station-keeping activities thus far key to any legal concerns. It meant that various legal regimes other than space law properly speaking could, would or should now become applicable to those activities as well, varying from criminal law to intellectual property rights relating to the protection of inventions made on board the ISS.

\subsection{The international character of the ISS venture and the position of Europe}

The unique international character of the whole undertaking came to be duly reflected in the legal construction. Legally speaking, all the preceding space stations constituted simple legal constructs as single-nation stations even if many foreign crew visited them. Following Article VIII of the Outer Space Treaty ${ }^{147}$ and Article II of the Registration Convention, ${ }^{148}$ the stations were registered by the respective states, and thereby qualified as their quasi-territory for legal purposes. Likewise, for example, liability for damages caused by the operations of such space stations would revert to those states in accordance with Article VII of the Outer Space Treaty and Articles I-V of the Liability Convention. ${ }^{149}$

With the refusal by the other partner states already under the 1988 Intergovernmental Agreement to simply register the whole ISS as a U.S. space object, the involvement of many jurisdictions came into play. Thus, under the Intergovernmental Agreements (both the 1988 and the 1998 versions) "each Partner shall register as space objects the flight elements [...] which it provides," and consequently will be principally entitled to "retain jurisdiction and control" over such elements as well as 
the personnel on board. ${ }^{150}$ In other words: legally speaking, the ISS consisted of a number of floating pieces of quasi-territory of the different states (Canada effectively being excluded as it was not to provide any manned element) linked to each other in the global commons of outer space.

A further unique element in this context was the explicit designation of ESA as a partner in the ISS undertaking. ${ }^{151}$ ESA, as an intergovernmental organization consisting of sovereign member states, does not and cannot exercise jurisdiction and legal control in the normal sense of the word. ${ }^{152}$ However, under certain conditions, the Registration Convention allows intergovernmental organizations to serve as the equivalent of a state for all practical purposes regarding the legal regime vis-à-vis parties-ESA indeed complies with those requirements and can thus effectively act as registration "state" for the European module of the ISS. ${ }^{153}$ This means that for any legal issues requiring the exercise of such "real" jurisdiction and legal control, reference will (have to) be made to the individual member states of ESA participating in the ISS as parties to the 1998 Intergovernmental Agreement.

\subsection{Commercialization of ISS utilization and "space tourism"}

Though originally not taken into consideration, ${ }^{154}$ it soon became clear that another novelty given birth by the ISS would be commercial utilization. It was partly the continued problems with governmental funding within various partner states that led them to start considering, in the late nineties, the possibilities of generating interest - and investments among private companies in using the ISS as opposed to merely being subcontracted to build elements or to use certain space-based products or services derived from ISS activities. The microgravity environment was considered of great potential interest, in particular, for medical and chemical industries, but other semi- or proto-commercial uses were also expected.

Thus, ESA, for example, was given the mandate in 1999 to promote the commercial utilization of the European module of the ISS, and officially such usage up to $33 \%$ in terms of available time was envisaged. ${ }^{155}$ Other partners arrived at similar constructions internally. ${ }^{156}$ This partial commercialization resulted once more in a broader scope of legal issues being at least potentially applicable to ISS operations and bringing in existing regimes such as liability and contract-related law - or even necessitating new legal instruments such as an ISS Crew Code of Conduct and a Multilateral Crew Operations Panel, all under the umbrella of the Intergovernmental Agreement. ${ }^{157}$ 
The most spectacular novelty, certainly for outsiders, was of course the advent of space tourism., which took its first aim at the ISS. In April 2001, U.S. citizen Dennis Tito was launched to the Russian part of the ISS for no other reasons than that he was driven by his desire to fly in outer space and happened to have the money privately available to pay the price quoted to him for fulfilling that desire. ${ }^{158}$

Originally Tito, through the brokerage of a small private company called MirCorp established specifically for bringing self-financed private persons into space, was supposed to be launched on a Russian launch vehicle to the Russian space station Mir, at an overall price estimated at the time to amount to some US \$20 million. In the course of his preparation, however, Mir had to be de-orbited, which occurred over the Pacific Ocean in March 2001. ${ }^{159}$ In order to honor their contractual commitment, the Russians had only one way out: to change Tito's destination to the Russian module of the ISS which was being built at the time.

Paying similar amounts for the privilege, a second millionaire, South African Mark Shuttleworth, followed suit in 2002; U.S. national Greg Olsen became the third space tourist in 2005; and Anousheh Ansari became the first female space tourist in 2006 - and all had the ISS as the destination for their week-long stay in outer space. ${ }^{160}$ It also became clear that this new branch of space activities created the distinct necessity to establish appropriate legal rules and principles, and to some extent - essentially at the national level within the U.S. - this has already been done. ${ }^{161}$

\section{Space law and the International Space Station}

Some of the major elements of the application of international space law to the ISS were briefly discussed in the preceding part, with a view to some novel characteristics as these have then been addressed in the Intergovernmental Agreement, but they merit a second look now.

\section{I. Jurisdiction in general}

Thus, the jurisdiction of individual partner states was seen to apply to respective parts of the ISS through the registration of the separate elements of the ISS as separate space objects, which as such was in compliance with the framework regime offered by Article VIII of the Outer Space Treaty and relevant clauses of the Registration Convention. ${ }^{162}$ However, how any potential conflict of laws was to be dealt with, for example when a U.S. and a Japanese astronaut/engineer would be involved in a legal issue on board the Russian module, was not elaborated further by the Intergovernmental 
Agreement, with two prominent exceptions. These concerned specific issues of jurisdiction considered immediate and important enough that they should not be permitted to be dealt with only by the time a conflict would have arisen and/or by means of general principles of conflict of laws: criminal jurisdiction and intellectual property rights jurisdiction.

\subsection{Criminal jurisdiction}

As for criminal jurisdiction, ${ }^{163}$ the prospect of the application of criminal laws on board of the ISS in view of the long duration of human presence in a limited space with a limited amount of others coming from various cultures and backgrounds was considered substantial enough, in spite of the extensive screening and training of astronauts and cosmonauts (and in spite of the cooperative approach to the whole venture) to warrant more detailed arrangements already at the level of the IGA itself.

Interestingly, dealing with this issue was to present one of the few key differences between the 1988 and 1998 versions of the Intergovernmental Agreements. In the older version, the case of a certain activity or event involving someone present on board the ISS raising questions of potential criminal liability was dealt with by application of quasi-territorial jurisdiction. The jurisdiction of the state on board of whose element that activity or event had occurred would apply in first instance; however, U.S. authorities could exercise their jurisdiction potentially overriding any other one if the activity or event posed a threat to the safety of operations on board the ISS ${ }^{164}$ - which, as one can imagine, could quite easily be the case.

In fact, this potentially overriding U.S. jurisdiction reflected the fact that any person to be prosecuted for acts on board of the ISS, under the old construct, could only be brought back to earth by means of a U.S. vehicle, as no other partner state at the time possessed manned spaceflight capability. Hence U.S. jurisdiction and control would have first choice. ${ }^{165}$ Obviously, that changed once Russia came on board, and since Russia did not appreciate this construct the relevant clauses were altered in the course of the negotiations.

Thus, Article 22(1) of the 1998 Intergovernmental Agreement now reads: "Canada, the European Partner States, Japan, Russia, and the U.S. may exercise criminal jurisdiction over personnel in or on any flight element who are their respective nationals." This is in essence the so-called .active personality-principle., well-known in general international law as a justification for exercising criminal jurisdiction. ${ }^{166}$ Article 22(2) then adds certain possibilities for other states to exercise their jurisdiction on the basis of passive nationality ${ }^{167}$ or quasi-territoriality, ${ }^{168}$ but this depends on the extent to which the state of nationality of the alleged perpetrator itself is interested in prosecution. 


\subsection{Jurisdiction and intellectual property rights protection}

While the application of criminal jurisdiction circumvented the additional problem of ESA-involvement, read ESA-registration of the European module, by applying the active personality-principle-ESA astronauts qualifying as nationals of respective ESA member states, with the qualification of part of the ISS as an ESA module. not being relevanta different approach was taken for jurisdiction relevant for applying intellectual property rights. Article 21(2) of the 1998 Intergovernmental Agreement applies the quasi-territorial approach, in that sense following the general regime of Article 5: "for purposes of intellectual property law, an activity occurring in or on a Space Station flight element shall be deemed to have occurred only in the territory of the Partner State of that element's registry."

Obviously then, in this case a further solution had to be found for the specific European context, where ESA does not have any "territory" in the legal sense of the word. Thus, "for ESA-registered elements any European Partner State may deem the activity to have occurred within its territory." 169 To date, two European states-Germany and Italy - have actually taken the trouble to extend the scope of their national, territorially-based legislation protecting inventions by means of patents to inventions done on board of the European module of the ISS. ${ }^{170}$ The result is that anyone entitled to claim a patent as regards an invention done on board of the European module of the ISS, whether of German, Italian or any other nationality (European or otherwise) should register his or her patent with either the German or the Italian authorities.

Firstly, based on the rather advanced measure of harmonization of intellectual property rights within Europe, the protection under such a registration does not only extend to those other European states but is also of a similar scope and nature. ${ }^{171}$ Secondly, based on conventions going back as far as 1883 (the so-called Paris Convention) ${ }^{172}$ and the activities of the World Intellectual Property Organisation (WIPO), ${ }^{173}$ such patents would turn out to be basically protected in most jurisdictions across the globe.

\subsection{Jurisdiction and "space tourists"}

A further issue, related to some extent to the general one of jurisdiction, arose suddenly some years after the Intergovernmental Agreement: the visit of the world's first space tourist in 2001 triggered, among other things, a discussion regarding the terminology used in the space treaties of "astronauts"174 and "personnel" of a spacecraft, ${ }^{175}$ which entailed cer- 
tain privileges pertaining to the special obligations of the relevant states to not only come to the rescue in case of distress, but also provide support in returning the persons concerned home as speedily as possible, without entertaining any thoughts about applying domestic jurisdiction, for whatever, reason, to those persons prior to their return home.

The ISS Crew Code of Conduct created another category of "spaceflight participants," where the term "spaceflight participant" referred to "an individual (e.g., ... crewmembers of non-partner space agencies, engineers, scientists, teachers, journalists, filmmakers or tourists), sponsored by one or more partner(s); normally this is a temporary assignment that is covered under a short-term contract; they are eligible for assignment as visiting scientist, commercial user or tourist, but their task assignment cannot include ISS assembly, operations and maintenance activities."176 By encompassing space tourists, it ensured that these would not enjoy those same privileges as astronauts or cosmonauts.

\subsection{The issue of liability for damage}

The next major issue that was dealt with at the level of the Intergovernmental Agreement itself in very fundamental terms, considering the potential threat it constitutes to the general cooperation spirit behind the whole venture, concerned the question about what should happen, should damage occur within the context of any of the activities related to the design, development, operation and utilization of the ISS.

Space law as it stood under the Liability Convention did provide for a somewhat elaborate system of liability for damage caused by space activities, more precisely caused by space objects; such liability was allocated to the launching state(s). ${ }^{177}$ Further clauses provided, for example, for the applicability of absolute respective fault liability, for joint and several liability, for the lack of a limit to compensation, for a jus standi under the Convention, for exculpatory clauses and for a rudimentary dispute settlement system. ${ }^{178}$ As may clearly be derived from many clauses in the Liability Convention, however, the liability system was very much geared to third- party liability, and not very helpful for application to cases of interparty liability, even though not formally excluded by the Convention. ${ }^{179}$

The Intergovernmental Agreement acknowledges this regime as being applicable to any damage caused by the ISS or any of its elements as space objects to third states, ${ }^{180}$ and then creates by means of Article 16 an extended regime for dealing with intra-party damage and the question of liability. Essentially, it provides for a cross-waiver of liability for damage caused in the context of what has been defined in a sweeping manner as "Protected Space Operations," 181 between not only the partners and part- 
ner states themselves, but also between any or all of the "related entities" of one such partner state and those of another partner state. ${ }^{182}$ There are a few exceptions to this cross-waiver, such as when it concerns private claims for bodily injury or death or claims for damage caused by willful misconduct, ${ }^{183}$ but overall, the spirit of cooperation has resulted in the need for each partner state and their related entities to simply accept the possibility that they may suffer damage in the context of the ISS without being able to assert a liability claim for the purpose.

\section{What comes next?}

In sum, the current legal arrangements at the level of the ISS itself, even as regards the main legal document which is the 1998 Intergovernmental Agreement, represent a highly interesting and innovative set of legal rules, rights and obligations resulting from the need to deal with the truly international character of the ISS. In particular, the additional novel element of the role of the European Space Agency as an intergovernmental organization has called for additional innovations in law-making. The ISS, novel as it may be also in legal terms, represents no more than an intermediate step in the broader adventure of mankind's expansion into outer space. Yet, in many respects, the ISS forebodes the legal issues to follow such expansion - and the legal construct supporting it has already come up with helpful legal solutions in some cases.

This is not the proper place to dwell long on the many, often futuristic, plans for future activities in outer space pertaining to long-duration human presence. It should suffice to say that with the human presence in outer space continuously being extended - and, presumably, made easier and cheaper by a magnitude or two - the number of legal issues that will become relevant at least theoretically will inevitably grow. When mankind actually establishes .space colonies. on celestial bodies, at least in the non-legal sense of the word because up to now colonization in the legal sense is clearly prohibited by Article II of the Outer Space Treaty, many of the issues discussed with regard to the ISS legal regime-criminal liability, intellectual property rights, liability for damage will become even more prominent. Moreover, new issues such as the nationality of space-born babies, the applicability of human rights to outer space, and the validity of contracts drawn up in outer space on outer space matters will present themselves in due course.

This may trigger discussions on whether jurisdiction, which is currently not possible on a territorial basis, should be structured differently so as to ensure that law will actually follow man into outer space. Or will jurisdiction based on the nationality of the humans involved suf- 
fice-but then, what about these future space-born humans? Even now, with the impending prospects of man returning to the moon and then on to Mars, issues such as safety-and/or security-zones around installations on celestial bodies, the exploitation of mineral resources in situ and other commercial issues such as licensing are back on the table. The fate of the Moon Agreement ${ }^{184}$ should warn us: after it had been drafted with the involvement and general consent of all important states concerned, a swift change in the global political climate caused all those to renege on actually ratifying and in most cases even signing it. Thus, it currently has only thirteen parties (including none of the major space-faring nations) plus four states only having signed the Agreement (including France and India); its relevance in legal terms is therefore to be severely doubted. Clearly, therefore, there is no easy road when it comes to building a legal regime acceptable and fair to all, as well as workable and efficient-but inevitably it is a road we must take, as the alternative would be considerably worse: a legal near- vacuum in outer space.

\section{Notes}

[Notes 1-136 refer to earlier chapters in the book.]

137 Rosmalen, S. "The International Space Station Past, Present and Future: An Overview." The International Space Station: Commercial Utilisation from a European Legal Perspective. von der Dunk, Frans G. and Brus, Marcel M. T. A. eds. Leiden: Brill, 2006. pp. 9-14.

138 Agreement among the Government of the United States of America, Governments of Member States of the European Space Agency, the Government of Japan, and the Government of Canada on Cooperation in the Detailed Design, Development, Operation, and Utilization of the Permanently Manned Civil Space Station (hereafter 1988 Intergovernmental Agreement), Washington, done 29 September 1988, entered into force 30 January 1992. Space Law - Basic Legal Documents, D.II.4.2.

139 This concerned Belgium, Denmark, France, Germany, Italy, the Netherlands, Norway, Spain, Sweden, Switzerland and the United Kingdom.

140 ESA was established by means of the Convention for the Establishment of a European Space Agency (hereafter ESA Convention), Paris, done 30 May 1975, entered into force 30 October 1980. 14 ILM 864 (1975). As of this writing, ESA counts seventeen member states. ESA pools the financial and technical resources of its member states to conduct research and development activities vis-à-vis or in outer space; the European contributions to the ISS are undertaken as optional programs, in accordance with Art. V(1. b), ESA Convention, which means inter alia that not necessarily all ESA member states have to participate.

141 Rosmalen, S. "The International Space Station Past, Present and Future: An Overview." The International Space Station: Commercial Utilisation from a European Legal Perspective. von der Dunk, Frans G. and Brus, Marcel M. T. A. eds. Leiden: Brill, 2006. pp. 11-14.

142 Agreement among the Government of Canada, Governments of Member States of the European Space Agency, the Government of Japan, the Government of the Russian Federation, and the Government of the United States of America concerning Cooperation on the Civil International Space Station (hereafter 1998 Intergovernmental Agree- 
ment), Washington, done 29 January 1998, entered into force 27 March 2001. Space Law-Basic Legal Documents, D.II.4.

143 Art. 9(3.a), 1998 Intergovernmental Agreement.

144 Art. 4, 1998 Intergovernmental Agreement.

145 This exception was provided by Art. 12, 1998 Intergovernmental Agreement, which in par. 2 allows for the provision of such services on "a reimbursable (...) basis."

146 Art. 1(1), 1998 Intergovernmental Agreement.

147 Treaty on Principles Governing the Activities of States in the Exploration and Use of Outer Space, including the Moon and Other Celestial Bodies (hereafter Outer Space Treaty), London/Moscow / Washington, done 27 January 1967, entered into force 10 October 1967. 610 UNTS 205. TIAS 6347. 18 UST 2410. UKTS 1968 No. 10. Cmnd. 3198. ATS 1967 No. 24. 6 ILM 386 (1967).

148 Convention on Registration of Objects Launched into Outer Space (hereafter Registration Convention), New York, done 14 January 1975, entered into force 15 September 1976. 1023 UNTS 15. TIAS 8480. 28 UST 695. UKTS 1978 No. 70. Cmnd. 6256. ATS 1986 No. 5. 14 ILM 43 (1975).

149 Convention on International Liability for Damage Caused by Space Objects (hereafter Liability Convention), London/Moscow/Washington, done 29 March 1972, entered into force 1 September 1972. 961 UNTS 187. TIAS 7762. 24 UST 2389. UKTS 1974 No. 16. Cmnd. 5068. ATS 1975 No. 5. 10 ILM 965 (1971).

150 Art. 5(1), resp. (2), 1998 Intergovernmental Agreement, which furthermore explicitly refers to Art. VIII, Outer Space Treaty, and Art. II, Registration Convention.

151 Art. 3(b), 4, 1998 Intergovernmental Agreement.

152 Shaw, Malcolm N. International Law. 3rd ed. Cambridge: Grotius Publications Limited, 1991. p. 393. "Jurisdiction concerns the power of the state to affect people, property and circumstances and reflects the basic principles of state sovereignty, equality of states and non-interference in domestic affairs." Thus, it is an exclusive prerogative belonging to states.

153 Art. VII(1), Registration Convention, in conjunction with Art. 5(1), 1998 Intergovernmental Agreement. ESA has formally complied with the requirements posed by the Registration Convention by a Declaration of 2 January 1979. Space Law-Basic Legal Documents, A.IV(4.2). 2.

154 Art. 9, 1998 Intergovernmental Agreement, on "Utilization" only referred to private entities in a general sense, and/or whether activities concerned would be conducted for peaceful purposes.

155 Belingheri, M. "A Policy and Legal Framework for Commercial Utilisation." The International Space Station: Commercial Utilisation from a European Legal Perspective. von der Dunk, Frans G. and Brus, Marcel M. T. A. eds. Leiden: Brill, 2006. p. 35.

156 Veldhuyzen, R. P. and Masson-Zwaan, T. L. “ESA Policy and Impending Legal Framework for Commercial Utilisation of the European Columbus Laboratory Module of the ISS." The International Space Station: Commercial Utilisation from a European Legal Perspective. von der Dunk, Frans G. and Brus, Marcel M. T. A. eds. Leiden: Brill, 2006. p. 51.

157 Ibid. p. 53.

158 Launius, Roger D. and Jenkins, Dennis R. "Is it finally time for space tourism?" Astropolitics 4 (2006): 255. Smith, Lesley J. and Hörl, Kai-Uwe. “Legal Parameters of Space Tourism." Proceedings of the Forty-Sixth Colloquium on the Law of Outer Space. Washington: American Institute of Aeronautics and Astronautics Inc, 2004. p. 38.

159 Billings, Linda. "Exploration for the masses? Or joy-rides for the ultra-rich? Prospects for space tourism." Space Policy 22 (2006): 163. Sattler, Rosanna. “U.S. Commercial 
Activities aboard the International Space Station." Air \& Space Law 28 (2003): 81.

160 Launius, Roger D. and Jenkins, Dennis R. "Is it finally time for space tourism?" Astropolitics 4 (2006): 260.

161 Most of those are not particularly or exclusively relevant in the context of the space station, if only since the main thrust of .space tourism. is rapidly shifting to the sub-orbital version currently being operationalized by the likes of Virgin Galactic; hence they will not be dealt with here. For further discussion of this new area of space law reference may soon be had to Von der Dunk, F. G. Passing the Buck to Rogers: International Liability Issues in Private Spaceflight. This article is to be published in the Nebraska Law Review in 2008.

162 Art. II, Registration Convention. Art. IV furthermore provides the main parameters to be included in the international registry with the UN Secretary-General, who in turn had delegated running the international registry to the UN Office for Outer Space Affairs (OOSA). UNOOSA. http://www.unoosa.org/oosa/en/SORegister/index.html

163 "Criminal jurisdiction" is defined as "power of tribunal to hear and dispose of criminal cases," whereas "criminal" is defined as "that which pertains to or is connected with the law of crimes, or the administration of penal justice, or which relates to or has the character of crime." West's Law \& Commercial Dictionary in Five Languages, Vol. I. St. Paul: West Publishing Company, 1985. pp. 386-387.

164 Art. 22, 1988 Intergovernmental Agreement.

165 The legal result thereof would be that any person of a different nationality than the U.S. one could only become effectively subject to the jurisdiction of his state of nationality after extradition by the U.S. to his state of nationality, extradition being a well-known international law-phenomenon hinging upon treaties calling for or even merely allowing for relevant cases of extradition. Shaw, Malcolm N. International Law. 3rd ed. Cambridge: Grotius Publications Limited, 1991. pp. 422-423. Wallace, Rebecca M. M. International Law. 3rd ed. London: Sweet \& Maxwell, 1997. pp. 119-121.

166 Shaw, Malcolm N. International Law. 3rd ed. Cambridge: Grotius Publications Limited, 1991. p. 403.

167 Ibid. pp. 408-409.

168 Ibid. pp. 402-403.

169 Art. 21(2), 1998 Intergovernmental Agreement.

170 Balsano, A. M. and Wheeler, J. "The IGA and ESA: Protecting Intellectual Property Rights in the Context of ISS Activities." The International Space Station: Commercial Utilisation from a European Legal Perspective. von der Dunk, Frans G. and Brus, Marcel M. T. A. eds. Leiden: Brill, 2006. pp. 65-67.

171 This harmonization process essentially takes place under the guidance of the Convention on the grant of European Patents, Munich, done 5 October 1973, entered into force 7 October 1977. p. 1065 UNTS 199. Cmnd. 7090; the Convention for the European Patent for the common market, Luxembourg, done 15 December 1975. Cmnd. 6553. 15 ILM 5 (1976). OJ L 401/9 (1989); and the Agreement relating to Community patents (89/695/EEC), Luxembourg, done 15 December 1989. OJ L 401/1 (1989).

172 Convention for the Protection of Industrial Property as Modified by Additional Act of 14 December 1900 and Final Protocol (hereafter Paris Convention), Paris, done 20 March 1883, entered into force 6 July 1884. USTS 379. UKTS 1907 No. 21. ATS 1907 No. 6. Later treaties further added to the scope and extent of global application and protection of patents and related rights, such as the Patent Cooperation Treaty, Washington, done 19 June 1970, entered into force 24 January 1978. 1160 UNTS 231. TIAS 8733. 28 UST 7645. Cmnd. 4530. UKTS 1978 No. 78. ATS 1980 No. 6. 9 ILM 978 (1970).

173 WIPO was established by means of the Convention Establishing the World Intellectual Property Organisation (WIPO), Stockholm, done 14 July 1967, entered into force 26 
April 1970. 828 UNTS 3. TIAS 6932. 21 UST 1749. UKTS 1970 No. 52. Cmnd. 3422. ATS 1972 No. 15. 6 ILM 782 (1967).

174 Art. V, Outer Space Treaty; title and Preamble of the Agreement on the Rescue of Astronauts, the Return of Astronauts and the Return of Objects Launched into Outer Space (hereafter Rescue Agreement), London/Moscow/Washington, done 22 April 1968, entered into force 3 December 1968. 672 UNTS 119. TIAS 6599. 19 UST 7570. UKTS 1969 No. 56. Cmnd. 3786. ATS 1986 No. 8. 7 ILM 151 (1968).

175 Art. VIII, Outer Space Treaty; Art. 1, 2, 3, 4, Rescue Agreement.

176 Veldhuyzen, R. P. and Masson-Zwaan, T. L. “ESA Policy and Impending Legal Framework for Commercial Utilisation of the European Columbus Laboratory Module of the ISS." The International Space Station: Commercial Utilisation from a European Legal Perspective. von der Dunk, Frans G. and Brus, Marcel. M. T. A. eds. Leiden: Brill, 2006. p. 55.

177 Art. I(c), Liability Convention.

178 Art. II, III, IV, V, XII, VIII, VI, XIV-XX, Liability Convention.

179 Such evaluation arises inter alia from clauses referring to cases involving more than one state in the causation of damage, where only the inter-party distribution of third-party liability was referred to, which depending upon the case was then explicitly or implicitly left for those states to deal with (Art. V (2), resp. Art. IV(2), Liability Convention), Art. III referring to damage done to the space object of another state, and Art. VII(b) inter alia excluding "foreign nationals [...] participating in the launch" from the scope of the Convention in case they suffer damage caused by the space object thus launched.

180 Art. 17, 1998 Intergovernmental Agreement.

181 Art. 16(2.f), 1998 Intergovernmental Agreement. This article defines such Protected Space Operations as "all launch vehicle activities, Space Station activities, and payload activities on Earth, in outer space, or in transit between Earth and outer space in implementation of this Agreement, the MOUs, and implementing arrangements," then taking care to even further elaborate the broad scope of the concept with further examples.

182 Art. 16(1), 1998 Intergovernmental Agreement. Art. 16(2.b) then defines "related entity" again very broadly as " (1) a contractor or subcontractor of a Partner State at any tier; (2) a user or customer of a Partner State at any tier; or (3) a contractor or subcontractor of a user or customer of a Partner State at any tier."

183 Art. 16(3d), 1998 Intergovernmental Agreement.

184 Agreement Governing the Activities of States on the Moon and Other Celestial Bodies (hereafter Moon Agreement), New York, done 18 December 1979, entered into force 11 July 1984. 1363 UNTS 3. ATS 1986 No. 14. 18 ILM 1434 (1979). 